\title{
Bioactivity of Schinus molle $L$. and Schinus terebinthifolia Raddi. Essential Oils on Anticarsia gemmatalis (Hübner 1818)
}

Camila Bonatto Vicenço ${ }^{1,2}$

https://orcid.org/0000-0003-0713-7707

Wendel Paulo Silvestre ${ }^{1,3, *}$

https://orcid.org/0000-0002-9376-6405

Verônica Tisatto da Silva ${ }^{2}$

https://orcid.org/0000-0002-5773-6217

Iriane Viganó Menegol ${ }^{2}$

https://orcid.org/0000-0002-7243-6247
Rahyssa Chagas Hahn ${ }^{2}$

https://orcid.org/0000-0001-8457-6629

Tiago Souza Lima ${ }^{3}$

https://orcid.org/0000-0002-9714-5796

Fabiana Agostini ${ }^{1}$

https://orcid.org/0000-0002-7627-1021

\section{Gabriel Fernandes Pauletti ${ }^{1,2,3}$}

https://orcid.org/0000-0001-9850-3682

1 University of Caxias do Sul (UCS), Institute of Biotechnology, Caxias do Sul, Rio Grande do Sul, Brazil; 2University of Caxias do Sul (UCS), Laboratory of Pest Control, Caxias do Sul, Rio Grande do Sul, Brazil; ${ }^{3}$ University of Caxias do Sul (UCS), Laboratory of Studies of the Soil, Plant and Atmosphere System and Plant Metabolism, Caxias do Sul, Rio Grande do Sul, Brazil.

Received: 2020.02.25; Accepted: 2020.04.17.

*Correspondence: wpsilvestre@ucs.br; Tel.: +55-54-3218-2965 (W.P.S.)

\section{HIGHLIGHTS}

- S. molle leaf had an EO yield of $0.3 \% \mathrm{~m} / \mathrm{v}$; S. terebinthifolia had $0.2 \% \mathrm{~m} / \mathrm{v}$.

- Both EOs presented $\alpha$-pinene as the major compound.

- S. molle EO induced $30 \%$ mortality of $A$. gemmatalis in $72 \mathrm{~h}$.

- S. terebinthifolia EO induced $70 \%$ mortality of $A$. gemmatalis in $72 \mathrm{~h}$.

- The $\mathrm{LC}_{50}$ for $S$. terebinthifolia EO was $1.74 \% \mathrm{v} / \mathrm{v}(1.58-1.97 \% \mathrm{v} / \mathrm{v})$.

Abstract: Anticarsia gemmatalis is one of the main pests of the soybean crop, being controlled mainly with agrochemicals. The environmental and health risks, as well as the development of resistance by the pests, has led to the search for alternative control measures, aiming to use more eco-friendly procedures. The objective of this research was to evaluate the chemical composition and the bioactivity of Schinus molle and Schinus terebinthifolia essential oils (EOs) on A. gemmatalis. The major compound in both EOs was a-pinene (60.04 wt.\% for S. molle and 38.49 wt.\% for S. terebinthifolia). Bioassays were carried out with third instar larvae, with five replicates and each replicate with ten larvae, totaling 50 larvae per treatment. The oils were incorporated in the artificial diet $(0.1,0.5,1.0,1.5$, and $2.0 \% \mathrm{v} / \mathrm{v})$. The controls were: water, Tween- $80^{\circledR} 0.5 \%$ $\mathrm{v} / \mathrm{v}$, and novaluron $0.075 \% \mathrm{v} / \mathrm{v}$. According to the Probit method, the S. terebinthifolia EO presented a $\mathrm{LC}_{50}$ of $1.74 \% \mathrm{v} / \mathrm{v}(1.58-1.97 \% \mathrm{v} / \mathrm{v})$; it was not possible to determine the $\mathrm{LC}_{50}$ for the $S$. molle EO. The mortality percentage after 24 and $48 \mathrm{~h}$ was $52 \%$ and $30 \%$ at $2.0 \% \mathrm{v} / \mathrm{v}$ for $S$. terebinthifolia and S. molle oil, respectively. 
After $72 \mathrm{~h}$, the mortality rate for S. molle EO have not changed; for S. terebinthifolia EO it increased to $70 \%$; the larvae treated with the chemical control (synthetic insecticide) had a mortality of $100 \%$.

Keywords: insecticidal activity; pest control; soybean caterpillar; terpenes; bioactive compounds.

\section{INTRODUCTION}

Soybean (Glycine $\max$ (L.) Merrill) is a plant of the Fabaceae family, which is native to China. Its grain is very versatile and gives rise to several by-products, which are used in the food, chemical, and agroindustries. Worldwide, soybean is considered one of the most economically important oilseeds, since it is a source of proteins and vegetable oil. It is also a feedstock for food industry, being also used in animal feeding [1].

Soybean cultivation represents the main crop for Brazilian agribusiness and has shown significant growth in the last decades due to advances in technology [2]. The yield in the $2018 / 2019$ harvest was $3,189 \mathrm{~kg} / \mathrm{ha}$, with a total production of more than 113 million of tons [3].

Anticarsia gemmatalis (Hübner, 1818) (Lepidoptera: Erebidae) is a tropical and subtropical species restricted to the American continent [4], being also considered a pest of legumes [5]. This pest can hinder the soy production potential, causing up to $100 \%$ defoliation and resulting in reduced crop yield [6].

As a result of the constant use of agrochemicals for pest control, these substances are losing their field effectiveness due to the excessive and frequent use of the same product in a certain area. The indiscriminate use of these products, in addition to polluting the environment, can lead to an increase in the selection of resistant insect populations, rendering it difficult to establish their natural enemies and also increasing the production costs $[7,8]$.

The negative impact of the massive use of synthetic pesticides on the environment and on human and animal health is widely reported in the literature and has stimulated the search for environment-friendly practices for controlling pests. The Integrated Pest Management (IPM) utilizes a combination of more environmentally friendly control methods in order to control pest populations in agricultural systems. The advantages of using botanical products include the rapid degradation of these molecules, low mammalian toxicity, high selectivity, and minimal impact on the plants [9].

The genus Schinus is native from the Americas, widely distributed throughout the continent; some species are also found in several tropical and subtropical areas of the world. Many of these species are cultivated due to their ornamental value in Australia, California, Mexico, the Canary Islands, and the Mediterranean [10].

Schinus molle L., original from Peru and considered native in Brazil (Rio Grande do Sul and Santa Catarina states), Uruguay, Argentina, and other countries of the Andean region [11], is a perennial, evergreen plant, fast-growing, reaching heights of 15 to $20 \mathrm{~m}$. The leaves are pinnate, distributed alternately; the branchlets and leaves are often pendant, and the small yellow flowers are abundant in terminal clusters. It produces flowers and fruits continually. The $S$. molle growth is greatest in the warm season, until soil moisture is depleted [12].

S. molle is used in its countries of origin in traditional and folk medicine, in beverages, and as a condiment; however, outside of its natural occurrence area, $S$. molle is cultivated for ornamental purposes. There are reports of this species as an invasive plant in Mexico, Australia, and South Africa [11,12].

Schinus terebinthifolia $\mathrm{L}$. is a perennial, evergreen plant, that can be found as a bush or as a tree, its height ranges from 5 to $10 \mathrm{~m}$, the plant trunk has a diameter between 20 and $30 \mathrm{~cm}$, coated by a shell with a thickness of 1 to $5 \mathrm{~mm}$. The shell is impregnated with a resinous material, which often appears on shell surface. The root is well developed, favoring its survival in harsh environments. Its leaves are dark-green, with a length of 10 to $15 \mathrm{~cm}$ and width of 2 to $3 \mathrm{~cm}$; the flowers have small size and the color ranges from yellow to white, the flowering period occurs in spring-summer months (September to January). The $S$. terebinthifolia fruits are small drupes, grouped in panicles, with a bright red color. Each fruit holds one seed with dark-brown color and a diameter of $0.3 \mathrm{~mm}$. Each plant generates numerous fruits. The fruiting occurs during the end of the summer and the autumn-winter period (January to July) [13].

Ferriter [14] cited S. terebinthifolia as an aggressively invasive pest plant in Hawaii, Florida, South Africa, Mascarene Islands, and Australia, causing several millions of dollars of damage and costs for its control. According to Silva-Luz and Pirani [15], the name $S$. terebinthifolius is a homotypic synonym for $S$. terebinthifolia; thus, the two scientific names correspond to the same species. 
The objective of the present work was to determine the chemical composition of the essential oils EOs of Schinus molle and Schinus terebinthifolia leaves obtained by hydrodistillation and to evaluate their bioactivity on Anticarsia gemmatalis.

\section{MATERIAL AND METHODS}

\section{Insects}

The $A$. gemmatalis larvae used in this study were grown using the artificial diet method proposed by Greene and coauthors [16] and kept in the Laboratory of Pest Control of the University of Caxias do Sul under controlled conditions $\left(26 \pm 1^{\circ} \mathrm{C}, \mathrm{RH}\right.$ of $75 \pm 1 \%$, and photoperiod of $14 \mathrm{~h}$ of light and $10 \mathrm{~h}$ of dark).

\section{Plant material and obtainment of essential oils}

Leaves from five plants of $S$. molle and five plants of $S$. terebinthifolia were collected in the early morning of September 10, 2019, in the city of Caxias do Sul, from the area around the Biotechnology Institute of the University of Caxias do Sul (UCS), and deposited in the herbarium of UCS (HUCS 47634 and HUCS 49320, respectively) [17]. Only one collection of plant material was carried out. The plant material was dried in a drying oven with forced air circulation at a constant temperature of $40{ }^{\circ} \mathrm{C}$ for 3 days.

The EOs from both plants were extracted by steam distillation of the leaves, following the process described by Koketsu and Gonçalves [18], for a period of $90 \mathrm{~min}$. The EOs were collected at the outlet of the condenser and put in amber bottles; a small sample of each EO was sent for GC/MS and GC-FID analyses and the remaining EOs were stored away from sunlight at $4 \pm 2{ }^{\circ} \mathrm{C}$. The oils were only brought to room temperature (approx. $25^{\circ} \mathrm{C}$ ) at the time of the bioassays.

\section{Chemical characterization of the essential oils}

The EO samples underwent qualitative analysis by GC/MS and quantitative analysis by GC-FID. The analyses were carried out at the Analytical Center of the Biotechnology Institute of the University of Caxias do Sul.

The GC-FID analysis was performed on a Hewlett Packard 6890 Series gas chromatograph, equipped with a HP-Chemstation data processor, using a HP-5 column $(30 \mathrm{~m} \times 320 \mu \mathrm{m}$ i.d. $)$ with $0.50 \mu \mathrm{m}$ film thickness (Hewlett Packard, Palo Alto, CA, USA). Temperature program: $40^{\circ} \mathrm{C}$ for $8 \mathrm{~min}$, increased to $180{ }^{\circ} \mathrm{C}$ at $3{ }^{\circ} \mathrm{C} / \mathrm{min}$, then increased to $230^{\circ} \mathrm{C}$ at $20^{\circ} \mathrm{C} / \mathrm{min}$, then maintained at $230^{\circ} \mathrm{C}$ for $20 \mathrm{~min}$; injector temperature of $250{ }^{\circ} \mathrm{C}$; split ratio of $1: 50$, flow rate of $1.0 \mathrm{~mL} / \mathrm{min}$, flame ionization detector with a temperature of $250{ }^{\circ} \mathrm{C}$; hydrogen as carrier gas at $34 \mathrm{kPa}$; injected volume of $1 \mu \mathrm{L}$ of EO diluted in hexane (1:10).

The GC/MS analysis was performed on a gas chromatograph coupled to a Hewlett Packard 6890/MSD5973 mass selective detector, equipped with HP-Chemstation software and a Wiley (Hoboken, NJ, USA) 275 spectra library. A HP-5 fused silica capillary column $(30 \mathrm{~m} \times 250 \mu \mathrm{m})$ with $0.50 \mu \mathrm{m}$ film thickness (Hewlett Packard). The temperature program used was the same as the one used in the GC-FID; interface temperature of $280{ }^{\circ} \mathrm{C}$, split ratio of $1: 100$, helium as the carrier gas at $56 \mathrm{kPa}$, flow rate of 1.0 $\mathrm{mL} / \mathrm{min}$, ionization energy of $70 \mathrm{eV}$, injected volume of $1 \mu \mathrm{L}$ of EO diluted in hexane (1:10).

The EO components were identified by comparison of their respective mass spectra to those of the Wiley Library, selected by the GC/MS software by match percentage, and comparing the calculated LRI (linear retention index) with the indexes reported by Adams [19]. The linear retention index (LRI) was calculated using the Van den Dool and Kratz equation, using a standard solution of alkanes (C8 to C26). Only the compounds whose LRI and mass spectrum data were concordant were considered as identified, otherwise, were considered as 'not identified'.

\section{Bioassays}

The EOs of $S$. molle and $S$. terebinthifolia were homogeneously diluted in the artificial diet. The concentrations were $(\% \mathrm{v} / \mathrm{v}): 0.1,0.5,1.0,1.5$, and 2.0 . Two negative controls were included: one with distilled water and the other with Tween- $80^{\circledR}(0.5 \% \mathrm{v} / \mathrm{v})$. A positive control with the chemical insecticide Rimon ${ }^{\circledR}$ Supra $(0.075 \% \mathrm{v} / \mathrm{v}$; novaluron as active ingredient) was also added to the experimental design.

Ten A. gemmatalis third instar larvae were used for each treatment and each control, with five replicates. The third instar phase was chosen because it is from this stage on that $A$. gemmatalis starts to cause crop losses. The insects were individually placed in $100 \mathrm{~mL}$ plastic cups with $1 \mathrm{~g}$ of the artificial diet containing the solubilized oil/control and a moist cotton pad to maintain the humidity. The mortality rates were evaluated 
after 24, 48, and $72 \mathrm{~h}$. The experiments were carried out at the Laboratory of Pest Control at the University of Caxias do Sul, Caxias do Sul, RS, Brazil.

\section{Statistical analysis}

The experimental design was bifactorial (factors: EO type and EO concentration), completely randomized, with five treatments, three controls, and five replicates. Each replicate was composed by ten larvae, totaling 50 larvae per treatment/control. The data underwent two-way analysis of variance (ANOVA), followed by the Tukey's multiple range test $(p<0.05)$. The statistical analyses were carried out using the Statistical Package for the Social Sciences (IBM SPSS for Windows 20.0) [20]. The Probit method [21] was used to determine the median lethal concentration $\left(\mathrm{LC}_{50}\right)$ values.

\section{RESULTS AND DISCUSSION}

\section{Chemical analysis of the essential oils}

The chemical constitution of the EOs from different cultivars depends on several factors, such as genetic, abiotic, and climatic factors; water stress; environmental stimulation; nutrition; the growth phase; the parts of the plant used; the collection season; drying conditions; and the EO obtainment method [22-25].

Regarding EO yield, in the present work the leaf oil of $S$. molle had a yield of $0.3 \% \mathrm{v} / \mathrm{m} ; S$. terebinthifolia leaf EO yield was $0.2 \% \mathrm{v} / \mathrm{m}$ (Table 1). Cavalcanti and coauthors [26] reported yields of $1.10 \% \mathrm{v} / \mathrm{m}$ and $0.10 \%$ $\mathrm{v} / \mathrm{m}$ for the leaf EOs of $S$. molle and S. terebinthifolia, respectively. Machado and coauthors [27] reported a yield of $0.78 \% \mathrm{v} / \mathrm{m}$ for $S$. molle leaf EO obtained by hydrodistillation. Uliana and coauthors [28] reported an EO yield of $1.70 \% \mathrm{v} / \mathrm{m}$ for the leaves of $S$. terebinthifolia.

According to the literature, the leaf EO from $S$. molle is mainly composed by monoterpenes and sesquiterpenes, such as $\alpha$-pinene, $\beta$-pinene, myrcene, limonene, $\beta$-caryophyllene, bicyclogermacrene, $\delta$ cadinene, spathulenol, and $\alpha$-cadinol $[11,26]$.

The EO of $S$. molle contained $\alpha$-pinene (60.04 wt.\%), limonene (11.28 wt.\%), and $\beta$-pinene (9.24 wt.\%) as the major compounds (Table 1). In other studies that characterized this oil, the major components identified were $\alpha$-pinene, sabinene, limonene, caryophyllene, terpineol, bicyclogermacrene, spathulenol, and $\mathrm{Y}$-muurolene [29]. Cavalcanti and coauthors [26] reported cubenol, caryophyllene oxide and spathulenol as the major compounds of $S$. molle leaf EO, with contents of $27.1,15.3$, and $12.4 \mathrm{wt}$.\%, respectively. Machado and coauthors [27] reported $\beta$-pinene, $\alpha$-pinene, limonene and muurolol as major compounds of the leaf EO of $S$. molle, with contents of $14.7,14.1,9.4$, and 11.8 wt. \%, respectively. 
Table 1. Qualitative and quantitative analysis of the Schinus molle and Schinus terebinthifolia leaf essential oils, obtained by steam distillation.

\begin{tabular}{|c|c|c|c|c|c|}
\hline \multirow{2}{*}{ Compound } & \multirow{2}{*}{$\begin{array}{l}\text { Chemical } \\
\text { class }\end{array}$} & \multirow{2}{*}{ Calc. LRI } & \multirow{2}{*}{ LRI Lit. ${ }^{1}$} & \multicolumn{2}{|c|}{ wt.\% } \\
\hline & & & & S. molle & S. terebinthifolia \\
\hline a-thujene & MT & 922 & 924 & - & $0.32 \pm 0.06$ \\
\hline$\alpha$-pinene & MT & 932 & 932 & $60.04 \pm 0.07$ & $38.67 \pm 4.45$ \\
\hline camphene & MT & 944 & 946 & $0.25 \pm 0.08$ & $0.43 \pm 0.21$ \\
\hline sabinene & MT & 968 & 969 & $0.55 \pm 0.12$ & - \\
\hline$\beta$-pinene & MT & 973 & 979 & $9.24 \pm 1.94$ & $12.34 \pm 3.75$ \\
\hline myrcene & MT & 983 & 988 & $1.75 \pm 0.66$ & $0.72 \pm 0.37$ \\
\hline$\alpha$-terpinene & MT & 1019 & 1014 & - & $1.26 \pm 0.89$ \\
\hline limonene & MT & 1024 & 1024 & $11.28 \pm 3.27$ & $8.48 \pm 2.25$ \\
\hline cis- $\beta$-ocimene & MT & 1037 & 1032 & $2.07 \pm 0.19$ & $0.21 \pm 0.07$ \\
\hline terpinen-4-ol & OMT & 1180 & 1174 & $0.22 \pm 0.04$ & $1.21 \pm 0.25$ \\
\hline a-terpineol & OMT & 1185 & 1186 & - & $1.88 \pm 0.69$ \\
\hline linalyl acetate & OMT & 1256 & 1254 & - & $0.17 \pm 0.09$ \\
\hline a-terpinyl acetate & OMT & 1342 & 1346 & $0.22 \pm 0.08$ & - \\
\hline a-copaene & $\mathrm{ST}$ & 1354 & 1348 & $0.17 \pm 0.10$ & $0.15 \pm 0.08$ \\
\hline$\beta$-cubebene & ST & 1381 & 1387 & - & $3.34 \pm 0.58$ \\
\hline$\beta$-elemene & ST & 1393 & 1389 & - & $1.32 \pm 0.36$ \\
\hline$\beta$-caryophyllene & ST & 1426 & 1417 & $2.32 \pm 0.74$ & $3.12 \pm 0.48$ \\
\hline cis- $\beta$-farnesene & ST & 1444 & 1440 & - & $0.15 \pm 0.06$ \\
\hline a-humulene & ST & 1456 & 1452 & $0.16 \pm 0.03$ & $0.67 \pm 0.13$ \\
\hline Y-muurolene & ST & 1476 & 1478 & - & $0.41 \pm 0.20$ \\
\hline germacrene-D & ST & 1487 & 1484 & $5.97 \pm 1.12$ & $3.14 \pm 0.62$ \\
\hline bicyclogermacrene & ST & 1502 & 1500 & - & $3.32 \pm 0.94$ \\
\hline Y-cadinene & ST & 1511 & 1513 & $0.22 \pm 0.20$ & $0.56 \pm 0.19$ \\
\hline$\delta$-cadinene & ST & 1519 & 1522 & - & $0.63 \pm 0.32$ \\
\hline cis-calamenene & ST & 1528 & 1528 & - & $1.38 \pm 0.26$ \\
\hline cis-nerolidol & OST & 1563 & 1561 & - & $2.16 \pm 0.39$ \\
\hline spathulenol & OST & 1573 & 1577 & - & $0.18 \pm 0.04$ \\
\hline caryophyllene oxide & OST & 1584 & 1582 & - & $1.53 \pm 0.28$ \\
\hline globulol & OST & 1590 & 1590 & - & $1.08 \pm 0.61$ \\
\hline viridiflorol & OST & 1596 & 1592 & - & $0.91 \pm 0.20$ \\
\hline ledol & OST & 1604 & 1602 & - & $0.19 \pm 0.08$ \\
\hline$\beta$-eudesmol & OST & 1644 & 1649 & - & $0.33 \pm 0.06$ \\
\hline a-cadinol & OST & 1647 & 1652 & - & $2.27 \pm 1.12$ \\
\hline a-santalol & OST & 1670 & 1674 & - & $0.92 \pm 0.65$ \\
\hline \multicolumn{2}{|c|}{ Hydrocarbon monoterpenes (MT) } & & & 85.18 & 62.44 \\
\hline \multicolumn{2}{|c|}{ Oxygenated monoterpenes (OMT) } & & & 0.44 & 3.26 \\
\hline \multicolumn{2}{|c|}{ Hydrocarbon sesquiterpenes (ST) } & & & 8.84 & 18.20 \\
\hline \multicolumn{2}{|c|}{ Oxygenated sesquiterpenes (OST) } & & & - & 9.57 \\
\hline Not identified & & & & 5.54 & 6.53 \\
\hline Yield (\% v/m) & & & & 0.3 & 0.2 \\
\hline
\end{tabular}

RT: retention time; Calc. LRI: calculated linear retention index; Lit. LRI: literature retention time; ${ }^{1}$ Adams [19]. The trace $(-)$ indicates absence of the component. 
The EO of $S$. terebinthifolia presented $\alpha$-pinene as the major compound (38.67 wt.\%), followed by $\beta$ pinene (12.34 wt.\%) and limonene (8.48 wt.\%) as the other major compounds (Table 1). Other works also cite $\alpha$-phellandrene, $\gamma$-cadinene, and $\beta$-phellandrene (34.38 wt.\%, $18.04 \mathrm{wt} . \%$, and $10.62 \mathrm{wt} . \%$, respectively) as the major compounds in this EO [30]. Cavalcanti and coauhtors [26] reported $\beta$-caryophyllene, $\alpha$-pinene, and germacrene-D as the major compounds in S. terebinthifolia leaf EO, with contents of 35.2, 28.1, and $15.5 \%$ wt.\%, respectively. Figure 1 presents the chromatograms of both EOs.
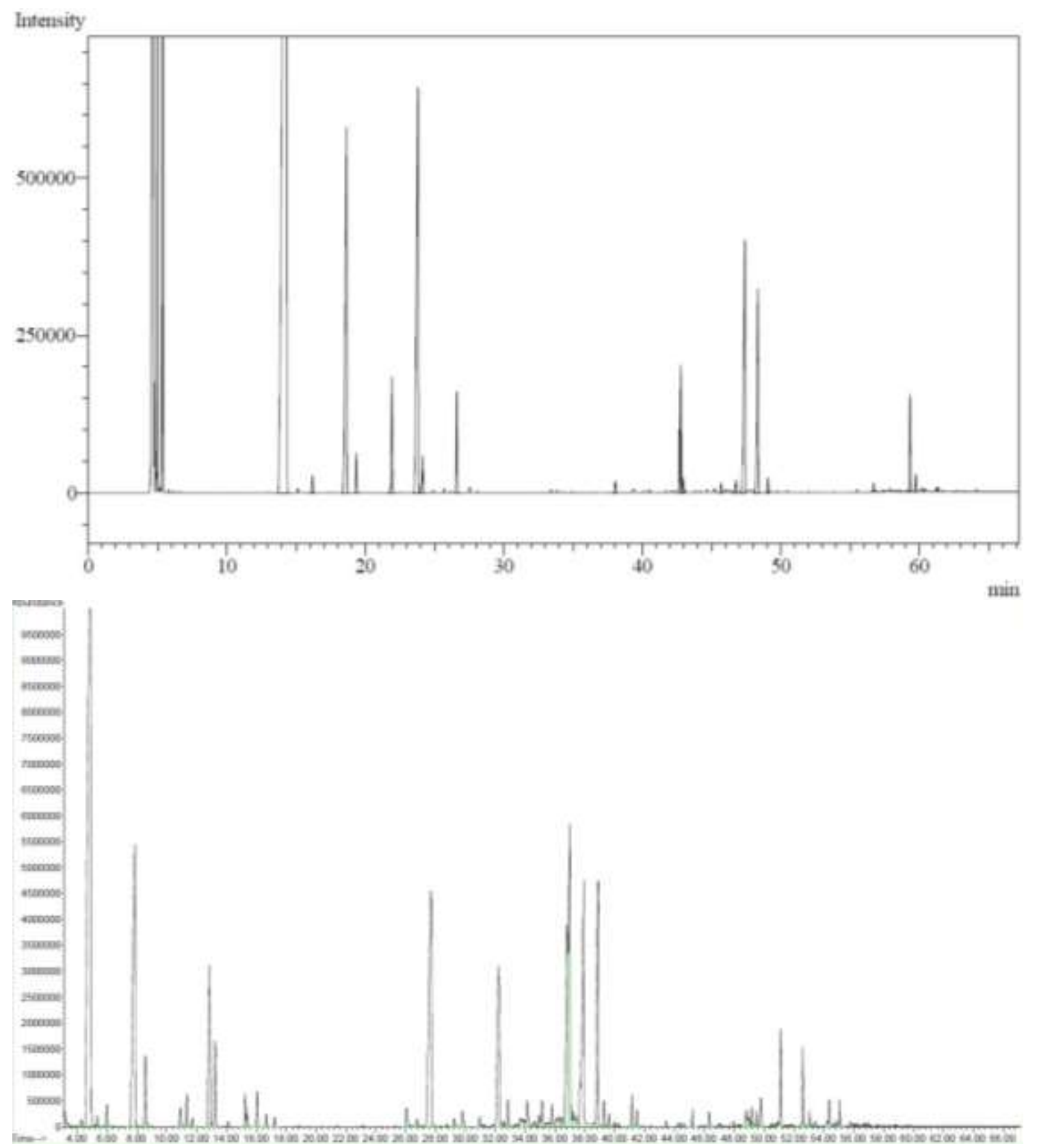

(B)

Figure 1. Chromatograms (GC/MS) of $S$. molle (A) and S. terebinthifolia (B) essential oils, obtained through steam distillation of the leaves.

Regarding chemical classes, hydrocarbon monoterpenes were the most abundant class (84.59 wt.\%) in the S. molle EO; it was also noteworthy the absence of oxygenated sesquiterpenes. Cavalcanti and coauthors [26] reported for $S$. molle leaf EO of plants from Southeastern Brazil and obtained after $6 \mathrm{~h}$ of hydrodistillation: hydrocarbon monoterpenes content of $4.2 \mathrm{wt} . \%$; a content of oxygenated monoterpenes of $25.6 \mathrm{wt} . \%$; the hydrocarbon sesquiterpenes presented a content of $4.5 \mathrm{wt} . \%$, and oxygenated sesquiterpenes accounted for $63.6 \mathrm{wt} . \%$ of the oil. Machado and caouthors [27] reported a hydrocarbon monoterpenes content of 38.8 wt.\%, oxygenated monoterpenes content of $14.0 \mathrm{wt} . \%$, hydrocarbon sesquiterpenes content of $10.3 \mathrm{wt} . \%$, and oxygenated sesquiterpenes content of $30.0 \mathrm{wt}$ \% for S. molle leaf EO of plants from South Brazil and obtained after $4 \mathrm{~h}$ of hydrodistillation. 
On the other hand, the $S$. terebinthifolia EO presented higher amounts of hydrocarbon sesquiterpenes (18.20 wt.\%) and also a small quantity of oxygenated sesquiterpenes (9.57 wt.\%). Cavalcanti and coauthors [26] reported the following composition for $S$. terebinthifolia leaf oil of plants from Southeastern Brazil, after $6 \mathrm{~h}$ of hydrodistillation: $41.2 \mathrm{wt}$ \% of hydrocarbon monoterpenes, $8.5 \mathrm{wt} . \%$ of oxygenated monoterpenes, and 50.3 wt.\% of sesquiterpenes; the authors also reported the absence of oxygenated sesquiterpenes in the oil. Uliana and coauthors [28] reported the following chemical class distribution for $S$. terebinthifolia leaf EO of plants from Southeastern Brazil, obtained after $2 \mathrm{~h}$ of hydrodistillation: $85.9 \mathrm{wt} \%$ of hydrocarbon monoterpenes, 0.5 wt. \% of oxygenated monoterpenes, 11.3 wt.\% of hydrocarbon sesquiterpenes, and 0.2 wt.\% of oxygenated sesquiterpenes.

Cavalcanti and caouthors [26], who studied the effect of process time in the extraction kinetics of EO from the leaves and fruits of both $S$. molle and $S$. terebinthifolia, reported an extraction pattern in which the monoterpenes were extracted firstly and more quickly, followed by a slower extraction of the sesquiterpenes. Taking into account that the authors reported a nearly complete extraction of the leaf EO after more than $6 \mathrm{~h}$ of process, that the EO yields in the present work for both plants were below the yields reported by the literature, and the differences between the EOs composition, mainly in relation to monoterpene and sesquiterpene contents, the extraction during 90 min have not extracted all of the EO components from the leaves of $S$. molle and $S$. terebinthifolia. Other factors that may have contributed (very probably in a lesser degree) for the differences between the EO compositions were the plant material being collected in different places, with different climates, soil type and nutritional state, and cultural management, since these factors can alter the EO composition and yield [31].

\section{Results of the bioassay}

The mortality rates for the individuals of $A$. gemmatalis treated with $S$. molle and $S$. terebinthifolia EOs after 24,48 , and $72 \mathrm{~h}$ are presented in the Tables 2, 3 and 4, respectively.

Table 2. Mortality percentages of $A$. gemmatalis after $24 \mathrm{~h}$ of exposure to the treatments and controls (CV $=21.49 \%)$.

\begin{tabular}{ccc}
\hline Treatment & \multicolumn{2}{c}{ Mortality (\%) in $\mathbf{2 4} \mathbf{~}$} \\
\cline { 2 - 3 } Water & S. molle & S. terebinthifolia \\
Tween-80 $0.5 \% \mathrm{v} / \mathrm{v}$ & $0.0 \mathrm{Ad}$ & $0.0 \mathrm{Ae}$ \\
Novaluron $0.075 \% \mathrm{v} / \mathrm{v}$ & $0.0 \mathrm{Ad}$ & $0.0 \mathrm{Ae}$ \\
$0.1 \% \mathrm{v} / \mathrm{v}$ & $38.0 \mathrm{Aa}$ & $38.0 \mathrm{Ab}$ \\
$0.5 \% \mathrm{v} / \mathrm{v}$ & $0.0 \mathrm{Ad}$ & $0.0 \mathrm{Ae}$ \\
$1.0 \% \mathrm{v} / \mathrm{v}$ & $6.0 \mathrm{Ad}$ & $0.0 \mathrm{Ae}$ \\
$1.5 \% \mathrm{v} / \mathrm{v}$ & $18.0 \mathrm{Ac}$ & $8.0 \mathrm{Bd}$ \\
$2.0 \% \mathrm{v} / \mathrm{v}$ & $20.0 \mathrm{Ac}$ & $18.0 \mathrm{Ac}$ \\
\hline
\end{tabular}

Means followed by the same letter, uppercase in row (EO type) and lowercase in column (concentration) do not present statistical difference by Tukey's multiple range test at $5 \%$ probability $(\alpha=0.05)$.

Relative to the EO kind, it can be seen in Table 2 that the EO performances differed only at the concentrations of 1.0 and $2.0 \% \mathrm{v} / \mathrm{v}$ in the first $24 \mathrm{~h}$, in which $S$. molle was more effective at $1.0 \% \mathrm{v} / \mathrm{v}(18 \%$ mortality) and S. terebinthifolia was more effective at $2.0 \% \mathrm{v} / \mathrm{v}(52 \%$ mortality).

Both oils presented no activity at the concentration of $0.1 \% \mathrm{v} / \mathrm{v}$ (Table 2$)$, which have not differed from the negative controls (water and Tween $-80^{\circledR} 0.5 \% \mathrm{v} / \mathrm{v}$ ). At $0.5 \% \mathrm{v} / \mathrm{v}, \mathrm{S}$. molle EO induced a slight mortality $(6 \%)$, whereas S. terebinthifolia oil presented no effect (zero mortality). At the concentration of $1.0 \% \mathrm{v} / \mathrm{v}$, the mortality induced by S. terebinthifolia oil was $8 \%$ in the first $24 \mathrm{~h}$ of evaluation, the $S$. molle EO performed better at this concentration, with a mortality rate of $18 \%$ (Table 2 ).

At higher concentrations ( 1.5 and $2.0 \% \mathrm{v} / \mathrm{v}$ ) there was a change in the mortality rates. Both oils performed similarly at $1.5 \% \mathrm{v} / \mathrm{v}$; at $2.0 \% \mathrm{v} / \mathrm{v}$ the EO of $S$. terebinthifolia induced a higher mortality $(52 \%)$ than the one of S. molle $(30 \% \mathrm{v} / \mathrm{v})$, in a reverse trend than the other concentrations (Table 2$)$.

Cole [32] reported that, for contact toxicity on Aedes aegypti larvae, S. terebinthifolia fruit EO (ס-3-carene as major compound) at the concentration of $200.4 \mu \mathrm{g} / \mathrm{mL}(0.024 \% \mathrm{v} / \mathrm{v})$ induced nearly $100 \%$ mortality after $24 \mathrm{~h}$. Silva and coauthors [33] observed, for S. terebinthifolia EO, a 100\% larvicidal mortality (by contact) of Stegomyia aegypti after $24 \mathrm{~h}$ of exposure at $862.70 \mu \mathrm{g} / \mathrm{mL}$ (approx. $0.1 \% \mathrm{v} / \mathrm{v}$ ). Chopa and coauthors [39] reported that $S$. molle leaf EO had no repellent activity on Blatella germanica L. 
Table 3. Mortality percentages of $A$. gemmatalis after $48 \mathrm{~h}$ of exposure to the treatments and controls $(\mathrm{CV}=17.25 \%)$.

\begin{tabular}{ccc}
\hline Treatment & \multicolumn{2}{c}{ Mortality (\%) in $\mathbf{4 8 ~} \mathbf{~}$} \\
\cline { 2 - 3 } Water & S. molle & S. terebinthifolia \\
\hline Tween-80 $0.5 \% \mathrm{v} / \mathrm{v}$ & $0.0 \mathrm{Ac}$ & $0.0 \mathrm{Ad}$ \\
Novaluron $0.075 \% \mathrm{v} / \mathrm{v}$ & $0.0 \mathrm{Ac}$ & $0.0 \mathrm{Ad}$ \\
$0.1 \% \mathrm{v} / \mathrm{v}$ & $78.0 \mathrm{Aa}$ & $78.0 \mathrm{Aa}$ \\
$0.5 \% \mathrm{v} / \mathrm{v}$ & $0.0 \mathrm{Ac}$ & $0.0 \mathrm{Ad}$ \\
$1.0 \% \mathrm{v} / \mathrm{v}$ & $6.0 \mathrm{Ac}$ & $0.0 \mathrm{Ad}$ \\
$1.5 \% \mathrm{v} / \mathrm{v}$ & $26.0 \mathrm{Ab}$ & $14.0 \mathrm{Bc}$ \\
$2.0 \% \mathrm{v} / \mathrm{v}$ & $26.0 \mathrm{Ab}$ & $18.0 \mathrm{Bc}$ \\
\hline
\end{tabular}

Means followed by the same letter, uppercase in row (EO type) and lowercase in column (concentration) do not present statistical difference by Tukey's multiple range test at $5 \%$ probability $(\alpha=0.05)$.

According to Table 3, after $48 \mathrm{~h}$ of exposure, there was little difference between the mortality rates regarding the ones in $24 \mathrm{~h}$. There was no difference between the EO types for the concentrations of 0.1 and $0.5 \% \mathrm{v} / \mathrm{v}$, which have not differed from the negative controls. For the remaining concentrations $(1.0,1.5$, and $2.0 \% \mathrm{v} / \mathrm{v}$ ), the oils presented different efficiencies; the oil of $S$. molle induced higher mortality rates at $1.0 \%$ $\mathrm{v} / \mathrm{v}(26 \%$ for S. molle and $14 \%$ for S. terebinthifolia) and $1.5 \% \mathrm{v} / \mathrm{v}(26 \%$ for $S$. molle and $18 \%$ for $S$. terebinthifolia). However, at $2.0 \% \mathrm{v} / \mathrm{v}$ both oils presented the same mortality rate as $24 \mathrm{~h}$, indicating that the oils at this concentration have not killed $A$. gemmatalis individuals in the time between 24 and $48 \mathrm{~h}$. In the other hand, the chemical control (novaluron $0.075 \% \mathrm{v} / \mathrm{v}$ ) induced a mortality rate of $78 \%$ after $48 \mathrm{~h}$, against $38 \%$ in the first $24 \mathrm{~h}$.

Relative to the EO concentrations, $1.0,1.5$, and $2.0 \% \mathrm{v} / \mathrm{v}$ have not differed for $S$. molle EO (Table 3). For S. terebinthifolia EO, the concentration of $2.0 \% \mathrm{v} / \mathrm{v}$ differed from 1.0 and $1.5 \% \mathrm{v} / \mathrm{v}$ (Table 3); in the first $24 \mathrm{~h}$ the 1.0 and $1.5 \% \mathrm{v} / \mathrm{v}$ differed between themselves (Table 2).

Silva and coauthors [33] reported that S. terebinthifolia EO induced a larval mortality of $100 \%$ of Stegomyia aegypti by contact after $48 \mathrm{~h}$ of exposure, at the concentration of $862.20 \mu \mathrm{L} / \mathrm{mL}$ (approx. $0.1 \%$ $\mathrm{v} / \mathrm{v}$ ). Abdel-Sattar and coauthors [34], who evaluated the insecticidal activity of $S$. molle EO, observed that the concentration of $1000 \mu \mathrm{L} / 10 \mathrm{~mL}$ (approx. $10.0 \% \mathrm{v} / \mathrm{v}$ ) induced $50 \%$ mortality of $T$. granarium individuals after $48 \mathrm{~h}$ of exposure.

Table 4. Mortality percentages of $A$. gemmatalis after $72 \mathrm{~h}$ of exposure to the treatments and controls (CV $=13.80 \%)$.

\begin{tabular}{ccc}
\hline Treatment & \multicolumn{2}{c}{ Mortality (\%) in $\mathbf{7 2 ~} \mathbf{~}$} \\
\cline { 2 - 3 } & S. molle & S. terebinthifolia \\
\hline Tween-80 $0.5 \% \mathrm{v} / \mathrm{v}$ & $0.0 \mathrm{Ad}$ & $0.0 \mathrm{Ae}$ \\
Novaluron $0.075 \% \mathrm{v} / \mathrm{v}$ & $0.0 \mathrm{Ad}$ & $0.0 \mathrm{Ae}$ \\
$0.1 \% \mathrm{v} / \mathrm{v}$ & $100.0 \mathrm{Aa}$ & $100.0 \mathrm{Aa}$ \\
$0.5 \% \mathrm{v} / \mathrm{v}$ & $0.0 \mathrm{Ad}$ & $0.0 \mathrm{Ae}$ \\
$1.0 \% \mathrm{v} / \mathrm{v}$ & $8.0 \mathrm{Ac}$ & $0.0 \mathrm{Be}$ \\
$1.5 \% \mathrm{v} / \mathrm{v}$ & $26.0 \mathrm{Ab}$ & $14.0 \mathrm{Bd}$ \\
$2.0 \% \mathrm{v} / \mathrm{v}$ & $26.0 \mathrm{Ab}$ & $24.0 \mathrm{Ac}$
\end{tabular}

Means followed by the same letter, uppercase in row (EO type) and lowercase in column (concentration) do not present statistical difference by Tukey's multiple range test at $5 \%$ probability $(\alpha=0.05)$.

Comparing the mortality rates in relation to EO type after $72 \mathrm{~h}$ of exposure, the concentrations of 0.5 , 1.0 , and $2.0 \% \mathrm{v} / \mathrm{v}$ differed between themselves, in which $S$. molle oil induced higher mortality rates at the lower concentrations $(0.5$ and $1.0 \% \mathrm{v} / \mathrm{v})$, and $S$. terebinthifolia oil induced it at the highest concentration $(2.0 \%$ $\mathrm{v} / \mathrm{v})$. It is noteworthy to observe that the mortality induced by concentration of $1.5 \% \mathrm{v} / \mathrm{v}$ has not differed between the EOs.

After $72 \mathrm{~h}$, the chemical control (novaluron $0.075 \% \mathrm{v} / \mathrm{v}$ ) induced $100 \%$ mortality of $A$. gemmatalis individuals, whereas the negative controls (water and Tween $-80^{\circledR} 0.5 \% \mathrm{v} / \mathrm{v}$ ) presented zero mortality. For $S$. molle EO, there was no difference between the negative controls and the concentration of $0.1 \% \mathrm{v} / \mathrm{v}$; for $S$. terebinthifolia EO, the concentrations of 0.1 and $0.5 \% \mathrm{v} / \mathrm{v}$ have not differed from the water and Tween- $80^{\circledR}$ treatments. 
It is also important to observe that the EO of $S$. terebinthifolia induced $70 \%$ mortality after $72 \mathrm{~h}$ at the highest concentration $(2.0 \% \mathrm{v} / \mathrm{v})$, whereas the EO of $S$. molle, at the same concentration, has not induced further mortality after $24 \mathrm{~h}$, with the mortality rate remaining as $30 \%$ during the entire test period (Table 4).

Ferrero and coauthors [36], evaluating the repellent activity of $S$. molle leaf extract, observed that the extract was effective on nymphs of Triatoma infestans. Silva and coauthors [33], who studied the insecticidal effect of $S$. terebinthifolia EO, reported $82 \%$ mortality of $S$. aegypti larvae after $72 \mathrm{~h}$ at the concentration of $775.68 \mu \mathrm{g} / \mathrm{mL}$ (approx. 0.09\% v/v). According to Abdel-Sattar and coauthors [34], the leaf EO of S. molle showed insecticidal activity on Tribolium castaneum, causing $90 \%$ mortality on the sixth day (144 h).

The larvicidal, insecticidal, and repellent activities of $S$. terebinthifolia fruit EO were evidenced against the Aedes aegypti mosquito, with concentrations of $169.20 \mu \mathrm{g} / \mathrm{mL}(0.02 \% \mathrm{v} / \mathrm{v}), 50 \mu \mathrm{L}\left(1.67 \mu \mathrm{L} / \mathrm{cm}^{2}-1.11 \cdot 10\right.$ $4 \% \mathrm{v} / \mathrm{v})$, and $2.39 \mathrm{wt} . \%(2.39 \% \mathrm{v} / \mathrm{v})$ being the most effective, respectively, in each of the performed tests [32]. However, there is little data on the toxicity of Schinus spp. leaf EOs against insects.

In the present study, $\alpha$-pinene (60.04 wt.\%), limonene (11.28 wt.\%), and $\beta$-pinene (9.24 wt.\%) were the major compounds identified in $S$. mole EO. In other studies, the major compounds reported were $p$-cymene (69.39 wt.\%), carvotanacetone (2.48 wt.\%), and $\alpha$-terpinene $(2.24 \mathrm{wt} . \%)$. In the present work, the major compounds identified in the $S$. terebinthifolia oil were $\alpha$-pinene (38.67 wt.\%), $\beta$-pinene (12.34 wt.\%), and limonene (8.48 wt.\%). Santos and coauthors [35] studied the EO of S. terebinthifolia, identifying germacreneD (25.0 wt.\%), (E)- $\beta$-caryophyllene (17.5 wt.\%), and $\delta$-elemene (10.5 wt.\%) as the leaf EO major compounds; the authors reported the EO caused $90 \%$ mortality of Hypothenemus hampei. The observed differences in the mortality rate for each EO might be due to the presence of minor compounds and even due to possible synergisms between EO compounds that enhance the biocidal effect of $S$. terebinthifolia EO on the larvae.

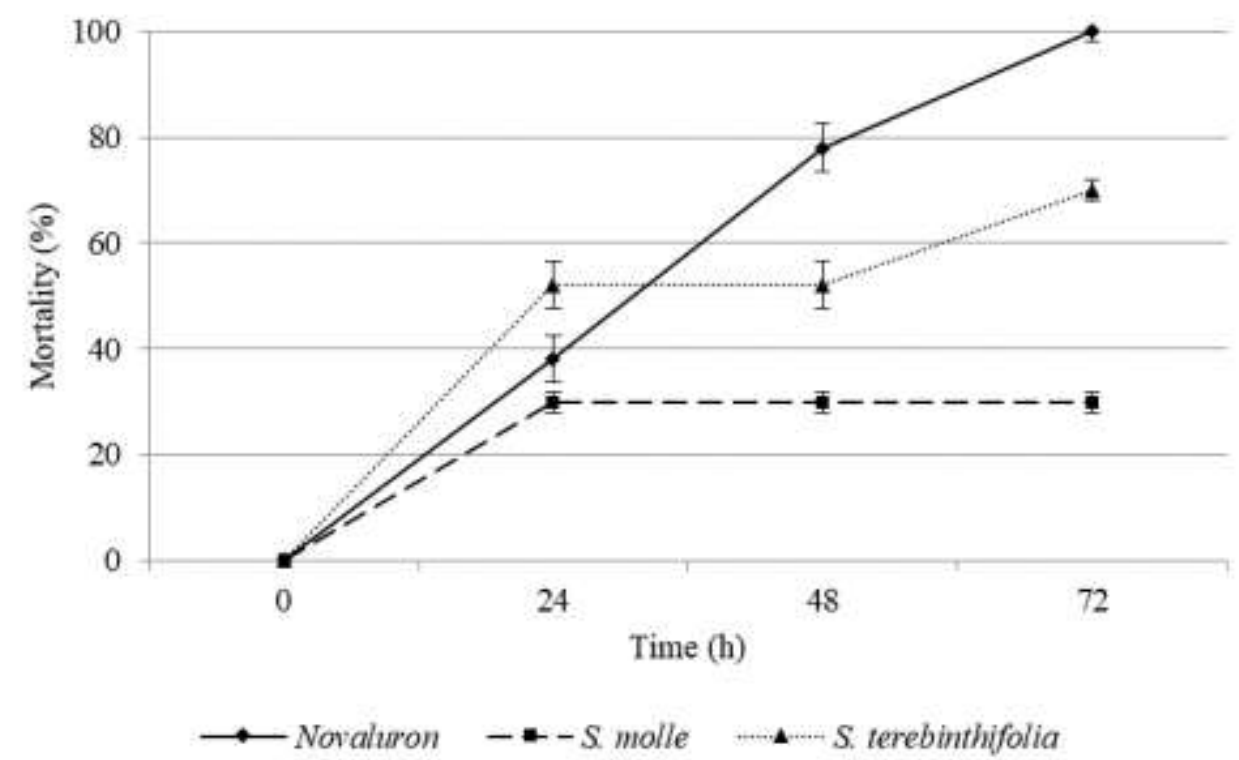

Figure 2. Evolution of $A$. gemmatalis mortality for the positive control (novaluron $0.075 \% \mathrm{v} / \mathrm{v}$ ) and the most effective concentration $(2.0 \% \mathrm{v} / \mathrm{v})$ of the essential oils of $S$. molle and S. terebinthifolia during the $72 \mathrm{~h}$ of bioassay.

It is noteworthy that the mortality rate pattern in function of the exposure time for both EOs at $2.0 \% \mathrm{v} / \mathrm{v}$ when compared to the positive control (novaluron $0.075 \% \mathrm{v} / \mathrm{v}$ ), as can be seen in Figure 2 . The EO of $S$. molle induced lower mortality rates (30\%) than the chemical insecticide (38\%) in the first $24 \mathrm{~h}$, unlike $S$. terebinthifolia EO, which induced $52 \%$ mortality. The oil of $S$. molle has not induced further increase of the mortality after 48 and $72 \mathrm{~h}$; the oil of $S$. terebinthifolia also presented the same mortality rate in 24 and $48 \mathrm{~h}$, whereas the chemical control presented a mortality rate of $78 \%$ after $48 \mathrm{~h}$. After $72 \mathrm{~h}$, the mortality rate induced by $S$. terebinthifolia EO was $72 \%$, whereas the chemical control induced $100 \%$ mortality of $A$. gemmatalis individuals.

In general, EOs are composed by terpenoids, which, depending on the chemical composition (mono-, sesqui-, or diterpenes) tend to be more easily oxidized or hydrolyzed. These reactions may reduce the efficiency of the EOs in the long-term [37]. Other factor that is important for the efficiency of EOs to control pests is the synergistic effect that may exist among the EO components. Omolo and coauthors [38] evaluated the repellent activity of some EOs and synthetic mixtures formulated with the major compounds, observing that the mixtures presented lower activity than the EO. This indicated that the minor compounds very probably also present repellent activity, or enhance the repellent activity of the major compounds. 
The higher efficiency of $S$. terebinthifolia EO may be result of the higher sesquiterpene content; these compounds have lower volatility and promote a more lasting contact effect on the insects than the oil of $S$. molle, whose large monoterpene fraction is highly volatile and may persist for smaller periods, promoting lower contact toxicity and less exposure time to the insects.

Regarding the $\mathrm{LC}_{50}$ of the oils after $72 \mathrm{~h}$, for $S$. terebinthifolia $\mathrm{EO}$ the $\mathrm{LC}_{50}$ was approximately $1.74 \% \mathrm{v} / \mathrm{v}$ $(1.58-1.97 \% \mathrm{v} / \mathrm{v}$, with a confidence interval of $95 \%)$. Taking into account that the maximum mortality rate for S. molle EO was $30 \%$ at $2.0 \% \mathrm{v} / \mathrm{v}$, the $\mathrm{LC}_{50}$ for this oil could not be determined. This also shows that $S$. terebinthifolia $\mathrm{EO}$ has had a superior insecticidal activity than S. molle $\mathrm{EO}$, probably due to the greater amounts of sesquiterpenes (27.77 wt.\% in S. terebinthifolia oil; 8.84 wt.\% in S. molle oil), which have lower volatility and also present toxic activity on insects.

Other authors have demonstrated that the EO of $S$. molle was effective at controlling Sitophilus zeamais, presenting an insecticidal effect during the evaluation of contact toxicity. The $\mathrm{LC}_{50}$ observed was $0.25 \mu \mathrm{L} / \mathrm{cm}^{2}$ $\left(2.5 \mathrm{~mL} / 100 \mathrm{dm}^{2}\right)$ and the $\mathrm{LC}_{99}$ was $1.92 \mu \mathrm{L} / \mathrm{cm}^{2}\left(19.2 \mathrm{~mL} / 100 \mathrm{dm}^{2}\right)$ [39]. Chopa and coauthors [40] studied the effect of the EO of $S$. molle on Blatella germanica L. and reported that $S$. molle leaf EO presented no repellent effect on this insect.

For S. terebinthifolia EO, Silva and coauthors [33] reported a $L_{50}$ of $862.20 \mu \mathrm{g} / \mathrm{mL}$ (approx. $0.1 \% \mathrm{v} / \mathrm{v}$ ) for Stegomyia aegypti. Cole [32] reported, for S. terebinthifolia fruit EO, a LD 50 of $117.34 \mu \mathrm{g} / \mathrm{mL}$ (approx. $0.014 \% \mathrm{v} / \mathrm{v})$ for Aedes aegypti.

According to the IPM method, a pest population control of approximately $50 \%$ is desirable to promote environmental equilibrium and avoid major changes in the biologic relations among species [9]. Therefore, S. terebinthifolia EO presented an adequate efficiency (52\% with $2.0 \% \mathrm{v} / \mathrm{v}$ in $24-48 \mathrm{~h}$ and $70 \%$ after $72 \mathrm{~h}$ ); whereas $S$. molle EO was relatively ineffective $(30 \%$ mortality with $2.0 \% \mathrm{v} / \mathrm{v}$ in $24-72 \mathrm{~h})$. However, it is important to point out that this is an in vitro screening, field tests must be carried out to verify the EO insecticidal activity in adverse (non-ideal) conditions.

The low yield of both oils may be a hindrance for an industrial use of these EOs, since the energy cost to obtain these materials are likely to make them economically unfeasible. Bioprospecting studies aiming to find specimens with higher EO yields may be necessary; there is also the issue of genetic variability, which may render several distinct chemotypes among the populations [11]. A possibility is the test and use of the major compound ( $\alpha$-pinene), which is a terpene widely distributed in nature [41]. Nevertheless, synergistic effects between $\alpha$-pinene and the minor compounds must be evaluated for a proper EO replacement.

Another issue is the potential allergenic and sensitizing effect of some terpenes, which may induce dermatitis and irritation of mucous membranes $[9,42]$. Considering that the terpenes are volatile and also biodegradable in variable periods, the main issue is relative to EO application; maybe a grace period prior to the manipulation of EO treated materials may be established, as already occurs to synthetic pesticides.

The results obtained suggest the need for further bioguided studies on the efficiency of the larvicidal properties of EOs in order to infer which compounds present insecticidal activity. Additional studies investigating the mechanisms of action, phytotoxicity, and safety to mammals and other vertebrates are also required.

\section{CONCLUSION}

The EO of $S$. terebinthifolia was effective (52\% mortality at an EO concentration of $2.0 \% \mathrm{v} / \mathrm{v}$ after $24-48$ $\mathrm{h}$, and $70 \%$ mortality after $72 \mathrm{~h}$ ) in the control of $A$. gemmatalis, whereas $S$. molle EO presented a lower mortality $(30 \%$ after $24-72 \mathrm{~h}$ at $2.0 \% \mathrm{v} / \mathrm{v})$. According to the Probit method, the $\mathrm{LC}_{50}$ for S. terebinthifolia EO was $1.74 \% \mathrm{v} / \mathrm{v}(1.58-1.97 \% \mathrm{v} / \mathrm{v}$ for $95 \% \mathrm{Cl})$; it was not possible to establish a $\mathrm{LC}_{50}$ for $\mathrm{S}$. molle EO due to the low mortality induced. This demonstrates the potential of $S$. terebinthifolia EO as an alternative to the use of chemical insecticides, whether used alone or associated with other substances, especially when applied using the guidelines provided by the IPM method.

Funding: This research received no external funding.

Acknowledgments: The authors would like to thank the team of Embrapa Soybean (Londrina, PR, Brazil), especially the researchers Adeney de Freitas Bueno and Nivaldo Ferreira Euclides, for providing the A. gemmatalis specimens.

Conflicts of Interest: The authors declare no conflict of interest. 


\section{REFERENCES}

1. Pieper R, Taciak M, Pieper L, Święch E, Tuśnio A, Barszcz M, Vahjen W, Skomial J, Zentek J. Comparison of the nutritional value of diets containing differentially processed blue sweet lupin seeds or soybean meal for growing pigs. Anim. Feed Sci. Technol. 2016; 221:79-86.

2. Oliveira CM, Souza Junior IT, Araújo Filho JV, Freitas MA, Rocha MR, Petrofeza S. Morphological, biochemical, and molecular characterization of Meloidogyne spp. populations from Brazilian soybean production regions. Cienc. Rural. 2017; 7:1-4.

3. IBGE. Instituto Brasileiro de Geografia e Estatística - SIDRA. 2019 [cited 2020 Feb 20]. Available from: https://sidra.ibge.gov.br/tabela/1618

4. Silva DM, Hoffmann-Campo CB, Bueno AF, Bueno RCF, Oliveira MC, Moscardi F. Biological characteristics of Anticarsia gemmatalis (Lepidoptera: Noctuidae) for three consecutive generations under different temperatures: understanding the possible impact of global warming on a soybean pest. Bull Entomol. Res. 2012; 102:285-92.

5. Biedma ME, Salvador RM, Ferrelli LA, Sciocco-Cap A, Romanowski V. Effect of the interaction between Anticarsia gemmatalis multiple nucleopolyhedrovirus and Epinotia aporema granulovirus, on A. gemmatalis (Lepidoptera: Noctuidae) larvae. Biol Control. 2015; 91:17-21.

6. Moscardi F, Bueno AF, Sosa-Gómez DR, Roggia S, Hoffmann-Campo CB, Pomari AF, Corso IC, Yano SAC. Artrópodes que atacam as folhas da soja. In: Hoffmann-Campo CB, Corrêa-Ferreira BS, Moscardi F, editors. Soja: manejo integrado de insetos e outros artrópodes-praga. Brasília: Embrapa; 2012. p. 213-334.

7. Hoffmann-Campo CB, Moscardi F, Corrêa-Ferreira BS, Oliveira LJ, Sosa-Gómez DR, Panizzi AR, Corso IC, Gazzoni DL, Oliveira EB. Pragas da soja no Brasil e seu manejo integrado. Londrina: Embrapa Soja; 2008. 70 p.

8. Moreira MD, Picanço MC, Silva EM, Moreno SC, Martins JC. Uso de inseticidas botânicos no controle de pragas. In: Venzon M, Paula Júnior TJ, Palinni A, editors. Controle alternativo de pragas e doenças. Viçosa: EPAMIG/CTZM; 2006. pp. 89-120.

9. Wiesbrook M. Natural indeed: are natural insecticides safer and better than conventional insecticides? Illinois Pesticide Rev. 2004; 17:1-8.

10. Zona S. The correct gender of Schinus (Anacardiaceae). Phytotaxa. 2015; 222:75-7.

11. Santos ACA, Rossato M, Agostini F, Almeida ML, Pauletti GF, Serafini LA, Moyna P, Dellacassa E. Caracterização química de populações de Schinus molle L. do Rio Grande do Sul. Rev. Bras. Bioci. 2007; 5: 1014-16.

12. Iponga DM. Invasive potential of the Peruvian pepper tree (Schinus molle) in South Africa [PhD thesis]. Stellenbosch: Stellenbosch University, 2009.

13. ANVISA. Monografia da espécie Schinus terebinthifolius Raddi (aroeira-da-praia) [cited 2020 Jan 17]. Available from: http://portalarquivos2.saude.gov.br/images/pdf/2014/novembro/25/Vers--o-cp-Schinus-terebinthifolius.pdf

14. Ferriter A (editor). Brazilian Pepper Management Plan for Florida. Brazilian Pepper Task Force, Florida Exotic Pest Plant Council, 1997.

15. Silva-Luz CL, Pirani JR. Anacardiaceae. In: Jardim Botânico do Rio de Janeiro. Lista de Espécies da Flora do Brasil. 2015 [cited 2019 Dec 22]. Avaliable from: http://floradobrasil.jbrj.gov.br/jabot/floradobrasil/FB15471

16. Greene GL, Leppla NC, Dickerson WA. Velvetbean Caterpillar: A Rearing Procedure and Artificial Medium. J. Econ. Entomol. 1976; 69: 487-8.

17. Thiers B. Index Herbariorum: A global directory of public herbaria and associated staff. New York Botanical Garden's Virtual Herbarium. 2019 [cited 2019 Dec 15]. Available from: http://sweetgum.nybg.org/science.ih/

18. Koketsu M, Gonçalves SL. Óleos essenciais e sua extração por arraste a vapor. Rio de Janeiro: EMBRAPA-CTAA; 1991. 24 p.

19. Adams RP. Identification of essential oil components by gas chromatography/mass spectrometry. 4th ed. Waco: Allured publishing; 2017. $809 \mathrm{p}$.

20. Green SB, Salkind NJ. Using SPSS for Windows and Macintosh: Analyzing and understanding data. 4th ed. New Jersey: Upper Saddle River; 2005. 458 p.

21. Finney DJ. Probit Analysis. 3rd ed. Cambridge: Cambridge University Press; 1971. 333 p.

22. Pinto JEBP, Cardoso JCW, Castro EM, Bertolucci SKV, Melo LA, Dousseau S. Morphophysiological aspects and essential oil content in brazilian-lavender as affected by shadowing. Hort. Bras. 2007; 25:210-4.

23. Baydar H. Lavender. Medicinal and Aromatic Plant Science and Technology. 3rd ed. Rhyad: Suleyman Demirel University Press; 2009. pp. 274-8.

24. Morais LAS. Influência dos fatores abióticos na composição química dos óleos essenciais. Hort. Bras. 2009; 27:4050-63.

25. Avci AB. A new record and distribution of the endemic Thymus cilicicus Boiss. \& Bal. for the squares B3 and C3 in Turkey. Turk. J. Field Crops. 2010; 15:40-2. 
26. Cavalcanti AS, Alves MS, Silva LCP, Patrocínio DS, Sanches MN, Chaves DSA, Souza MAA. Volatiles composition and extraction kinetics from Schinus terebinthifolius and Schinus molle leaves and fruit. Rev. Bras. Farmacog. 2015; 25:356-62.

27. Machado CD, Raman V, Rehman JU, Maia BHLNS, Meneghetti EK, Almeida VP, Silva RZ, Farago PV, Khan IA, Budel JM. Schinus molle: anatomy of leaves and stems, chemical composition and insecticidal activities of volatile oil against bed bug (Cimex lectularius). Rev. Bras. Farmacog. 2019; 29:1-10.

28. Uliana MP, Fronza M, Silva AG, Vargas TS, Andrade TU, Scherer R. Composition and biological activity of Brazilian rose pepper (Schinus terebinthifolius Raddi) leaves. Ind. Crops Prod. 2016; 83:235-40.

29. Barroso MST, Vargas RMF. Óleo essencial de Schinus molle L.: extração por arraste a vapor, modelagem matemática e análise química. Proceedings of the 10th Salão de Iniciação Científica PUCRS; 2009; Porto Alegre, Brazil [cited 2019 Nov 29]. Available from:http://www.pucrs.br/edipucrs/XSalaoIC/Engenharias/Engenharia_Quimica/70631-MAUREAN_SALLY_TAVARES_BARROSO.pdf.

30. Bendaoud H, Romdhane M, Souchard JP, Cazaux S, Bouajila J. Chemical Composition and Anticancer and Antioxidant Activities of Schinus molle L. and Schinus terebinthifolius Raddi Berries Essential Oils. J. Food. Sci. 2010; 75:466-72.

31. Christofoli M, Costa ECC, Bicalho KU, Domingues VC, Peixoto MF, Alves CCF, Araújo WL, Cazal CM. Insecticidal effect of nanoencapsulated essential oils from Zanthoxylum rhoifolium (Rutaceae) in Bemisia tabaci populations. Ind. Crops Prod. 2015; 70:301-8.

32. Cole ER. Estudo fitoquímico do óleo essencial dos frutos de aroeira (Schinus terebinthifolius RADDI) e sua eficácia no combate ao dengue [dissertation]. Vitória: Universidade Federal do Espírito Santo; 2008. 82 p.

33. Silva AG, Almeida DL, Ronchi SN, Bento AC, Scherer R, Ramos AC, Cruz ZMA. The essential oil of Brazilian pepper, Schinus terebinthifolia Raddi in larval control of Stegomyia aegypti (Linnaeus, 1762). Parasite. Vecto. 2010; 3:1-7.

34. Abdel-Sattar E, Zaitoun AA, Farag MA, Gayed SH, Harraz FMH. Chemical composition, insecticidal and insect repellent activity of Schinus molle L. leaf and fruit essential oil against Trogoderma granarium and Tribolium castaneum. Nat. Prod. Res. 2010; 24:226-35.

35. Santos MRA, Lima RA, Silva AG, Lima DKS, Sallet LAP, Teixeira CAD, Facundo VA. Composição química e atividade inseticida do óleo essencial de Schinus terebinthifolius Raddi (Anacardiaceae) sobre a broca-do-café (Hypothenemus hampei) Ferrari. Rev. Bras. PI. Med. 2013; 15:757-62.

36. Ferrero AA, Werdin JOG, Chopa CS. Biological activity of Schinus molle on Triatoma infestans. Fitoterapia. 2006; 77:381-3.

37. Pavela R, Benelli G. Essential oils as ecofriendly biopesticides? Challenges and constraints. Trends Plant Sci. 2016; 21:1000-6.

38. Omolo MO, Okinyo D, Ndiege IO, Lwande W, Hassanali A. Repellency of essential oils of some Kenyan plants against Anopheles gambiae. Phytochemistry. 2004; 65:2797-802.

39. Fernandes ET, Favero S. Óleo essencial de Schinus molle L. para o controle de Sitophilus zeamais Most.1855 (Coleoptera: Curculionidae) em milho. Rev. Bras. Agroec. 2014; 9:225-31.

40. Chopa CS, Alzogaray R, Ferrero A. Repellency assays with Schinus molle var. areira (L.) (Anacardiaceae) essential oils against Blattella germanica L. (Blattodea: Blattellidae). BioAssay. 2006; 1:6.

41. Salehi B, Upadhyay S, Orhan IE, Jugran AK, Jayaweera SLD, Dias DA, Sharopov F, Taheri Y, Martins N, Baghalpour N, Cho WC, Sharifi-Rad J. Therapeutic Potential of $\alpha$ - and $\beta$-Pinene: A Miracle Gift of Nature. Biomolecules. 2019; 11:738-72.

42. Preedy VR. Essential Oil in Food Preservation, Flavor and Safety. San Diego: Academic Press; 2016. 816 p. 